\title{
Production of Ethanol by Zymomonas Mobilis Mutant : The Effects of Sodium Acetate at pH 5 and No Control pH
}

\author{
Puspa Puspita, Hsieh Chia-Wen, and Chang Yao-Sheng
}

\begin{abstract}
Zymomonas mobilis is an ethanol producer that has the highest ethanol yield on sugar complex-containing glucose and the potential microorganism to replace yeast for ethanol production (ethanol yields up to 97\%). The lignocellulosic pretreatment is needed to increase the ethanol production. However, pretreatment methods will create some inhibitor compounds such as acetic acid that reduces ethanol production. The aims of this study were to know the effect of sodium acetate as a form of acetic acid in medium fermentation that contain higher glucose consentration at $\mathrm{pH} 5$ and no control $\mathrm{pH}$. As reported in this study, the effect of the increasing $\mathrm{NaAc}$ level related to the $\mathrm{pH}$. The growth of AcR/2-12 and ZM481 for $24 \mathrm{~h}$ at pH 5 were inhibited by NaAc concentration above $100 \mathrm{mM}$. However, the mutant strain AcR/2-12 on fermentation medium contained $100 \mathrm{~g} / \mathrm{l}$ glucose and supplemented with $195 \mathrm{mM} \mathrm{NaAc}$ at pH 5 was still able to grow well and produced $60 \mathrm{~g} / \mathrm{l}$ ethanol with the ethanol yield of 0.62 $\mathrm{g} / \mathrm{g}$ (Yproduct/substrate) in $148 \mathrm{~h}$. Whereas, without no control $\mathrm{pH}, \mathrm{AcR} / 2-12$ was able to tolerate $\mathrm{NaAc}$ up to $250 \mathrm{mM}$ and ZM481 was significantly inhibited at $195 \mathrm{mM}$ NaAc. Under the same condition with no control $\mathrm{pH}$, the glucose was completely consumed in $24 \mathrm{~h}$ by AcR/2-12 and $57 \mathrm{~g} / \mathrm{l}$ ethanol was produced with the ethanol yield of $0.58 \mathrm{~g} / \mathrm{g}(\mathrm{Yp} / \mathrm{s})$.
\end{abstract}

Index Terms-Zymomonas mobilis, ethanol, lignocellulosic, sodium acetate.

\section{INTRODUCTION}

The continuous depletion of the fossil fuels reserves and consequent escalation in their prices have stimulated an extensive evaluation of alternative technologies and substrates to meet the global energy demand. As a result, alternative sources of energy such as methane, hydrogen and ethanol are increasingly being considered as potential substitutes for fossil fuels. Ethanol is considered to be the most promising as an alternative liquid fuel, since it can be produced from a variety of agriculture-based renewable materials such as sugarcane bagasse, corn stover, barley straw, almond shells, wheat straw, potatoes and other agricultural products [1].

Ethanol could be produced by metabolisms of

Manuscript received February 5, 2019; revised April 29, 2019.

Puspa Puspita is with the Department of Biochemistry, Bogor Agricultural University, Bogor, West Java, Indonesia 16680 (e-mail: puspajulistia@gmail.com, puspa.julistia@apps.ipb.ac.id).

Hsieh Chia-Wen is with Department of Microbiology, Immunology and Biopharmaceuticals, National Chiayi University (NCYU), No. 300, University Rd. Chia-Yi, Taiwan, R.O.C. (e-mail: cwhsieh@mail.ncyu.edu.tw).

Chang Yao-Shang was with Department of Microbiology, Immunology and Biopharmaceuticals, National Chiayi University (NCYU)., No. 300, University Rd. Chia-Yi, Taiwan, R.O.C. (e-mail: s0973072@mail.ncyu.edu.tw). microorganisms. Production of ethanol by microorganisms can reduce the production cost and give high yield of ethanol. Microorganisms such as Saccharomyces cerevisiae, Pichia stipitis, Zymomonas mobilis and Escherichia coli have been used for ethanol production. Currently, S. cerevisiae is world widely used as the major ethanol-producing microorganism. Despite its extensive use, it has some disadvantages, such as high aeration cost, high biomass production, low temperature and ethanol tolerance [2]

Zymomonas mobilis is a facultatively anaerobic gram-negative. Z. mobilis also exhibits a high uptake rate of sugars, fermenting sugars to ethanol at specific rates [3]. Furthermore, the production of ethanol approaches theoretical maximum yields (97\%), while S. cerevisiae only achieved 90-93\% [4]. These are advantages of Z. mobilis utilization for generating higher ethanol production. Thus, $Z$. mobilis is a promising alternative microorganism to replace $S$. cerevisiae as an ethanol fuel producer.

The utilization of materials unsuitable for human consumption are considered as ideal substrates for bio-ethanol production, e.g. lignocellulosic. Lignocellulosic materials such as agriculture residues, softwoods, and hardwoods are an abundant and renewable source for ethanol production by fermentation. However, this materials contain lignin in the plant cell wall, and pretreatment process using chemical is necessary to make them available for enzymatic hydrolysis and fermentation [5]. From this pretreatment process often create toxic compounds which inhibit subsequent microbial fermentation. The dilute acid pretreatment process increases organic acids, primarily acetic acid, sugar degradation products such as furfural and hydroxylmethylfurfural (HMF), phenolics from lignin degradation as well as inorganic salts mainly arising from the pretreatment process [6].

Acetic acid is an important inhibitor produced by the deacetylation of hemicelluloses during biomass pretreatment, because in the uncharged and un-dissociated forms able to permeate the bacterial plasma membrane leading to un-coupling and anion accumulation causing cytoplasmic acidification [7]. If acetate is not removed, it may reach inhibitory levels when hydrolysates are concentrated to provide high final ethanol concentration. Therefore, this inhibitor must be removed or alternatively, candidate $Z$. mobilis strain for metabolic engineering needs to be resistant to this substance. The inhibition effect of acetic acid is dependent on the concentration of the un-dissociated species (HAc). The un-dissociated form of acetic acid (HAc) freely penetrates from outside of cell to inside. After the HAc penetrates, it would dissociate to ionic forms and generate protons, which lead to the reduction of $\mathrm{pH}$ value inside the 
cell. At low $\mathrm{pH}$, free acetic acid denominates, whereas at high $\mathrm{pH}$, the ion form dominates. The concentration of the toxic species, HAc, decreases exponentially as the $\mathrm{pH}$ increases.

The extensive reviews were conducted on inhibitors formed by pretreatment of lignocellulosic materials and their inhibition levels on ethanol production in yeast and bacteria [8]-[11]. One approach to overcome the issue of inhibition caused by pretreatment methods is to physically or chemically remove the inhibitor after pretreatment from the biomass, which requires extra equipment and time leading to increase costs. A second approach utilizes inhibitor-tolerant microorganisms for efficient fermentation of lignocellulosic material to ethanol and their utility is considered an industrial requirement [12], [13].

Currently, Z. mobilis ZM4/AcR mutant has been discovered to accomplish the problem due to the existence of acetic acid. This mutant was isolated from chemical mutagenesis with $\mathrm{N}$-methyl $\mathrm{N}$-nitro-N-nitrosoguanidine (NTG) treatment, and its characterization has been reported [13]. This acetate tolerant mutant was capable to produce ethanol efficiently on $100 \mathrm{~g} / \mathrm{l}$ glucose in the presence of $20 \mathrm{~g} / \mathrm{l}$ $\mathrm{NaAc}$ at $\mathrm{pH} 5,30{ }^{\circ} \mathrm{C}$ while the parent ZM4 was inhibited significantly at $12 \mathrm{~g} / \mathrm{l}$ sodium acetate under the same conditions.

Originally, Z. mobilis only produce ethanol by uptake glucose as a source carbon. However the recombinant strain of Zymomonas mobilis ZM4 (pZB5) has been found and it is capable of converting both glucose and xylose to ethanol. According to the previous study, the new mutant of $Z$. mobilis strain had been successfully isolated through NTG treatment from our laboratory, the name of that strain was $Z$. mobilis mutant AcR/2-12. AcR/2-12 in RM medium (20 g/l glucose) could survive in the presence of $16 \mathrm{~g} / \mathrm{l} \mathrm{NaAc}(195$ $\mathrm{mM}$ ) at $\mathrm{pH}$ 5, while the parent ZM481 (ATCC 31823) [14] was significantly inhibited under the same conditions. This mutant had been proven as $\mathrm{Na}^{+}$tolerance, but not Actolerance. However, the ability of this strain to produce ethanol in higher concentration of glucose, such as $100 \mathrm{~g} / \mathrm{l}$ and $200 \mathrm{~g} / \mathrm{l}$ containing different forms of acetate ( $\mathrm{NaAc}$, KoAc, HAc) has not been studied yet.

We assumed higher glucose concentration could provide more source carbon for Z. mobilis to grow and produce ethanol. Even though the increasing of glucose concentration can also stimulate the increasing in proportions of acetic acid and causes inhibition of ethanol production [14]. Thus, in this study we examined the effect of sodium acetate in higher glucose concentration containing the increasing $\mathrm{NaAc}$ level on the growth, ethanol production and glucose consumption and also to further understanding the effect of sodium acetate on the growth of AcR/2-12 at pH 5 and with no control pH.

\section{PROCEDURE}

\section{A. Microorganisms}

Zymomonas mobilis ZM481 (ATCC 31823) and a mutant derived from ZM481 (AcR/2-12) used in this work were obtained from Microbiology Laboratory of National Chiayi University. The mutant strain AcR/2-12 was generated by $\mathrm{N}$-methyl-N'-nitro-N-nitrosoguanidine (NTG) [12]. For use in this experiments, the cultures were maintained on agar containing $20 \mathrm{~g}$ glucose $/ \mathrm{l}, 5 \mathrm{~g}$ yeast extract $/ \mathrm{l}, 1.5 \mathrm{~g} / \mathrm{l}$ Amonium sulphate, $2 \mathrm{~g} / 1 \mathrm{KH}_{2} \mathrm{PO}_{4}, 1 \mathrm{~g} / 1 \mathrm{MgSO}_{4} .7 \mathrm{H}_{2} \mathrm{O}, 15 \mathrm{~g} / \mathrm{l}$ agar.. Colonies were grown on this medium for 3 days at $30^{\circ} \mathrm{C}$ then stored at $4^{\circ} \mathrm{C}$ for no longer than 1 week before use as inocula in liquid media.

\section{B. Media}

Inoculum Media. Inoculum media was used in this study was rich rich medium (RM) consisted of (g/l) $20 \mathrm{~g}$ glucose/l, $5 \mathrm{~g}$ yeast extract/l, $1.5 \mathrm{~g} / 1$ Amonium sulphate, $2 \mathrm{~g} / 1 \mathrm{KH}_{2} \mathrm{PO}_{4}, 1$ $\mathrm{g} / \mathrm{l} \mathrm{MgSO}_{4} \cdot 7 \mathrm{H}_{2} \mathrm{O}$. The components of these media were autoclaved at $121^{\circ} \mathrm{C}$ for 15 mins separately into three parts (dextrose, yeast extract and others chemical).

Fermentation media (FM). FM were identical in composition to the RM except the concentration of glucose up to $100 \mathrm{~g} / \mathrm{l}$ were added, and contained $\mathrm{NaAc}$ as a inhibitor. These experiments were carried out at $\mathrm{pH} 5$ and no control $\mathrm{pH}$.

\section{The Growth Performance of Z. Mobilis Mutant} AcR/2-12 and Wild-Type ZM481 in Medium Containing the Increasing Concentration of Sodium Acetate (NaAc)

Colonies of $Z$. mobilis taken from plates were grown for 16 $\mathrm{h}$ without shaking at $30^{\circ} \mathrm{C}$ in $\mathrm{RM}$ medium to mid growth phase. The $10 \%$ inoculums cells were inoculated into fermentation medium at $\mathrm{pH} 5$ and with no control $\mathrm{pH}$ that contained various concentration of sodium acetate $0,50,100$, $150,195,250 \mathrm{mM}$. Fermentation process was conducted without shaking at $30^{\circ} \mathrm{C}$ and the growth was determined by measuring the optical density at $600 \mathrm{~nm}$ by spectrophotometer (BIO-RAD, Smart Spec ${ }^{\mathrm{TM}} 3000$ ) for $36 \mathrm{~h}$. The ethanol and glucose concentration were measured by HPLC (Chrom Tech CH-300) analysis.

\section{Analytical Methods}

Viable cells were determined by plate count. Colonies of $Z$. mobilis could be known on the solid medium after 2-3 days incubation

The ethanol and glucose concentration in the fermentation and culture experiments were analyzed using high-performance liquid chromatography (HPLC) (Chrom Tech, CH-300) with a Shodex SUGAR SH1011, 8.0 x 300 $\mathrm{mm}$ column. The column temperature was maintained at $60^{\circ} \mathrm{C}$ and the mobile phase $\left(5 \mathrm{mM} \mathrm{H}_{2} \mathrm{SO}_{4}\right)$ was kept at 0.6 $\mathrm{ml} / \mathrm{min}$ flow rate.

Ethanol measurement. Ethanol standards were prepared by mixing $\mathrm{ddH}_{2} \mathrm{O}$ with various concentration of ethanol. The concentration of ethanol were $0.25,0.5,0.75,1,2,3,4,5$ (\%), and total amount of solution was $1 \mathrm{ml}$ were transferred to the eppendorf $1.5 \mathrm{ml}$ for HPLC analysis. The injection volume was $50 \mu$ l. The calibration line was then plotted. Calibration line is a relationship between ethanol concentration and the area (nRIU*s). Samples from fermentation medium were prepared as follows. After O.D. measurement, $1 \mathrm{ml}$ sample was centrifuged by a microcentrifuge for 10 minutes at 13000 rpm. Supernatants were collected. $100 \mu \mathrm{l}$ supernatants were

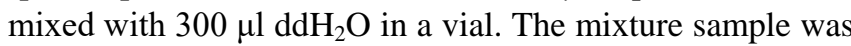
passed through a $0.45 \mu \mathrm{m}$ membrane filter and injected into the column. Area (nRIU*s) of each sample was obtained. Ethanol concentration was then calculated from the 
calibration line. Ethanol concentration will be calculated into $\mathrm{Y} \mathrm{p} / \mathrm{s}=$ product yield $(\mathrm{g}$ ethanol produced / $\mathrm{g}$ substrate consumed).

Glucose measurement. HPLC analysis allows simultaneous measurement for ethanol, and glucose. Calibration lines for glucose were prepared with $\mathrm{ddH}_{2} \mathrm{O}$ also. Concentrations of glucose in fermentation samples were calculated from calibration curves.

\section{RESULTS AND DISCUSSION}

\section{A. The Ethanol Production on Fermentation Medium Containing $100 \mathrm{~g} / \mathrm{l}$ and $200 \mathrm{~g} / \mathrm{l}$ of Glucose in the Absence of Inhibitor Compounds}

Results of the growth performance Z. mobilis mutant and wild-type are shown in Fig. 1. The growth of Z. mobilis mutant and wild-type on FM medium containing $100 \mathrm{~g} / \mathrm{l}$ was similar to each other (Fig. 1). Glucose was completely utilized by AcR/2-12 and produced $61.45 \mathrm{~g} / \mathrm{l}$ ethanol with the ethanol yield (Y product/substrate) of $0.63 \mathrm{~g} / \mathrm{g}$ within $28 \mathrm{~h}$. Meanwhile, the wild-type was completely utilized glucose within $24 \mathrm{~h}$ and produced $55.71 \mathrm{~g} / \mathrm{l}$ ethanol with the ethanol yield $(\mathrm{Yp} / \mathrm{s})$ of $0.58 \mathrm{~g} / \mathrm{g}$. The performances in medium containing $200 \mathrm{~g} / \mathrm{l}$ glucose were better than those performances in $100 \mathrm{~g} / \mathrm{l}$ glucose by those two strains (Fig. 2).

According to the graphs were showed in Fig. 1 and Fig. 2, the fermentation obtained $111.5 \mathrm{~g} / \mathrm{l}$ ethanol with the ethanol yield of $0.63 \mathrm{~g} / \mathrm{g}$ and $108.4 \mathrm{~g} / \mathrm{l}$ ethanol with the ethanol yield of $0.68 \mathrm{~g} / \mathrm{g}$ by AcR/2-12 and ZM481, respectively. Therefore, the fermentation in higher glucose concentration showed a linear relation to ethanol production. Thus, utilization higher glucose concentration would produce higher ethanol concentration.

A comparison of these two fermentation conditions showed that glucose consumption in $100 \mathrm{~g} / \mathrm{l}$ glucose more efficient than in $200 \mathrm{~g} / \mathrm{l}$ glucose. Fermentation in $100 \mathrm{~g} / \mathrm{l}$ glucose showed that the glucose was completely utilized within 36 hours and no remaining glucose in the medium feed. Contrarily, the remaining glucose in the medium feed was observed in the fermentation of ethanol using $200 \mathrm{~g} / \mathrm{l}$ glucose.

In those graphs below showed that using the higher glucose could produce the higher ethanol, however in another experiment proved that using higher glucose concentration will reduce the ethanol production. Another study reported on batch fermentation sugar (wheat starch) concentration as high as $223 \mathrm{~g} / \mathrm{l}$ could be fermented to $105 \mathrm{~g} / \mathrm{l}$ ethanol in seventy hours [15]. Another study by Allais et al. found that the volumetric productivity was $67.2 \mathrm{~g} / \mathrm{l} / \mathrm{h}$ with final ethanol concentration of $42 \mathrm{~g} / \mathrm{l}$ from $100 \mathrm{~g} / \mathrm{l}$ initial sugars from Jerusalem artichoke Juice using ZM4F of $Z$. mobilis [16].

The utilization of higher glucose concentration should be considered, because sometimes using higher glucose concentration can reduce ethanol production. Some studies have discovered the effect of higher glucose concentration. Kesava et al. mentioned that $Z$. mobilis has revealed that a higher glucose concentration at levels between 100 and 250 g/l can be efficiently and rapidly converted to ethanol. However, an increase in glucose concentration from $100 \mathrm{~g} / \mathrm{l}$ to $200 \mathrm{~g} / \mathrm{l}$ results in a significant decrease in the specific growth rate, cell yield, and ethanol yield [17]. Higher glucose concentrations also increase the total time of fermentation and lead to incomplete utilization of glucose. The effect of these high glucose concentrations on glucose utilization is found to be due to a limitation of metabolic activity under specified sets of conditions [18]. Panesar et al. suggested 50 - $150 \mathrm{~g} / \mathrm{l}$ as the best glucose concentration for high ethanol yield efficiency [19]. Acording to this study, concentation $100 \mathrm{~g} / \mathrm{l}$ glucose is the best concentration.

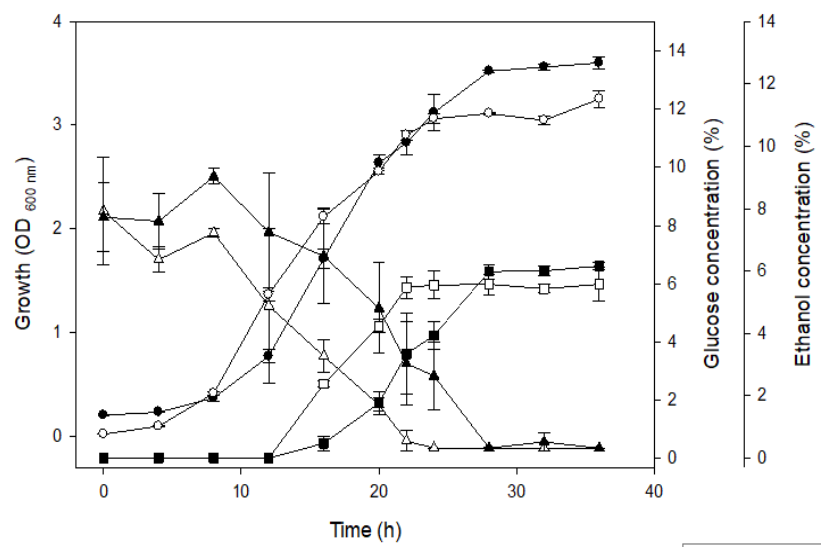

Fig. 1. Kinetic fermentation of $Z$. mobilis mutant AcR/2-12 and wild-type ZM481 in $100 \mathrm{~g} / \mathrm{l}$ glucose for $36 \mathrm{~h}$ fermentation time at $30^{\circ} \mathrm{C}$, with no control pH. • : AcR/2-12 (Growth) ; O : ZM481 (Growth) ; $\boldsymbol{\Delta}:$ AcR/2-12 (Glucose ) ; $\triangle$ : ZM481 (Glucose) ; $\mathbf{\square}:$ AcR/2-12 (Ethanol) ; $\square$ : ZM481 (Ethanol).

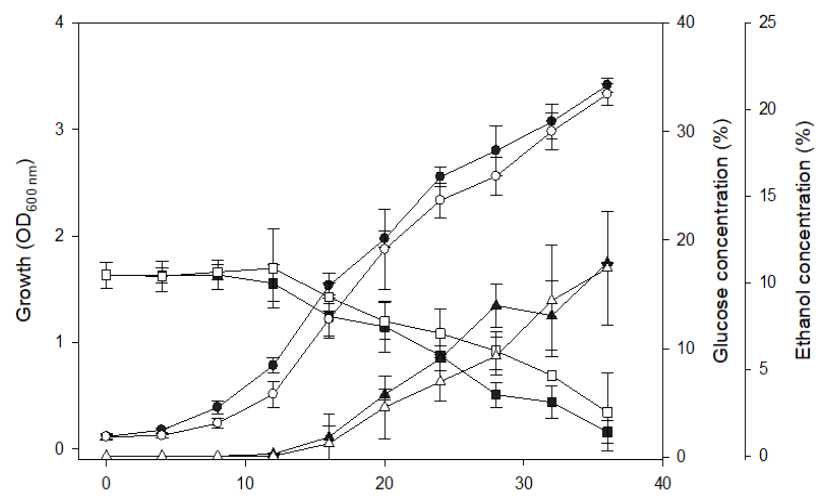

Fig. 2. Kinetic fermentation of Z. mobilis mutant AcR/2-12 and wild-type ZM481 in $200 \mathrm{~g} / \mathrm{l}$ glucose for $36 \mathrm{~h}$ fermentation time at $30^{\circ} \mathrm{C}$, with no control pH. - : AcR/2-12 (Growth) ; O : ZM481 (Growth) ; $\boldsymbol{\Delta}:$ AcR/2-12 (Glucose ) ; $\triangle$ : ZM481 (Glucose) ; $\mathbf{\square}:$ AcR/2-12 (Ethanol) ; $\square:$ ZM481 (Ethanol)

\section{B. The Effect of Sodium Acetate (NaAc) on the Growth and Ethanol Production with No Control $\mathrm{pH}$}

The growth performances in higher glucose concentration showed ethanol production was increased. Since, there was no inhibitor compound in the fermentation medium, $Z$. mobilis could metabolize substrate efficiently. In this study, $Z$. mobilis AcR/2-12 performed under stress condition to further understanding the ability of this mutant as an acetate-tolerance mutant to resist to NaAc. This experiments were carried out in $100 \mathrm{~g} / \mathrm{l}$ glucose concentrations with supplemented the increasing $\mathrm{NaAc}(0,50,100,150,195,250)$ $\mathrm{mM}$ level with no control $\mathrm{pH}$ and $\mathrm{pH} 5$. 


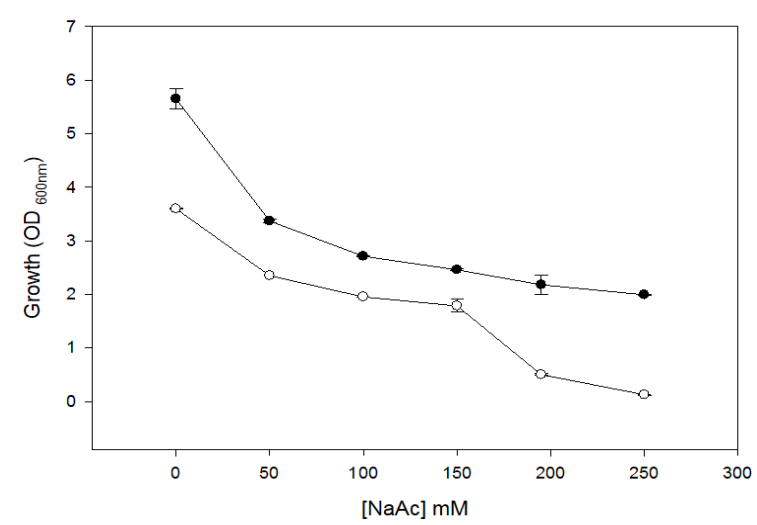

Fig. 3. The effect of the increasing NaAc level $(0-250 \mathrm{mM})$ on the growth of AcR/2-12 and ZM481 in $100 \mathrm{~g} / \mathrm{l}$ glucose for $24 \mathrm{~h}$ fermentation time with no control pH. • : AcR/2-12 (Growth) ; O : ZM481 (Growth).

Ethanol fermentation with no control $\mathrm{pH}$ with supplemented the increasing NaAc levels in $100 \mathrm{~g} / \mathrm{l}$ glucose exhibited effect of sodium acetate on the growth of ZM481 and AcR/2-12. The increasing initial NaAc level was significantly reduced the cell density (O.D values) and significantly inhibited the cell growth when $\mathrm{NaAc}$ level reached $250 \mathrm{mM}$. As showed in Fig. 3, AcR/2-12 was able to grow in the presence of $\mathrm{NaAc}$ up to $250 \mathrm{mM}$, while the growth of wild-type ZM481 was inhibited above $150 \mathrm{mM}$ $(12.5 \mathrm{~g} / \mathrm{l})$. The effect of $\mathrm{NaAc}$ also affected ethanol production and glucose consumption (Fig. 4).

The increasing NaAc level caused glucose consumption was inhibited thus occurred reduction of ethanol production. AcR/2-12 showed better performances than ZM481, indicated by the glucose consumption and ethanol production.

The glucose was consumed completely within 24 hours by AcR/2-12 under high concentration of NaAc. Whereas in ZM481, the glucose consumption was inhibited by NaAc concentration above $150 \mathrm{mM}$, thus no significant ethanol accumulation was observed within 24 hours fermentation time.

Fig. 4 B shows that in the presence of $195 \mathrm{mM} \mathrm{NaAc}$, the mutant could produce ethanol as well as that in the absence of $\mathrm{NaAc}$ in 24 hours, whereas at the same NaAc concentration, ZM481 was strongly inhibited.

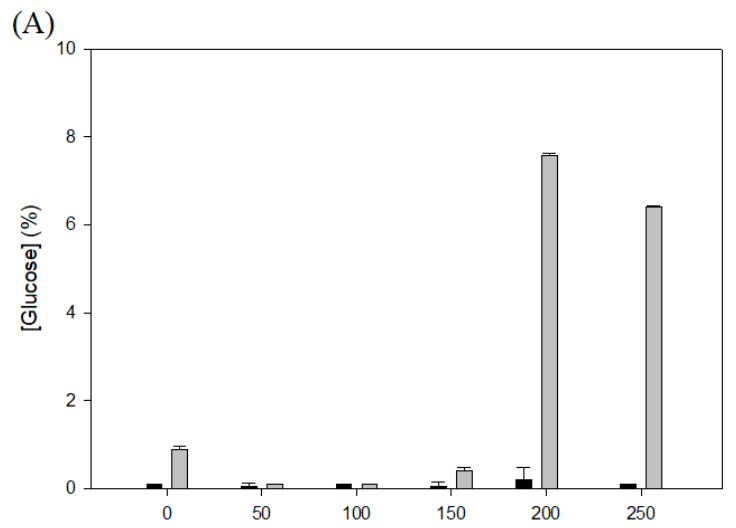

(B)

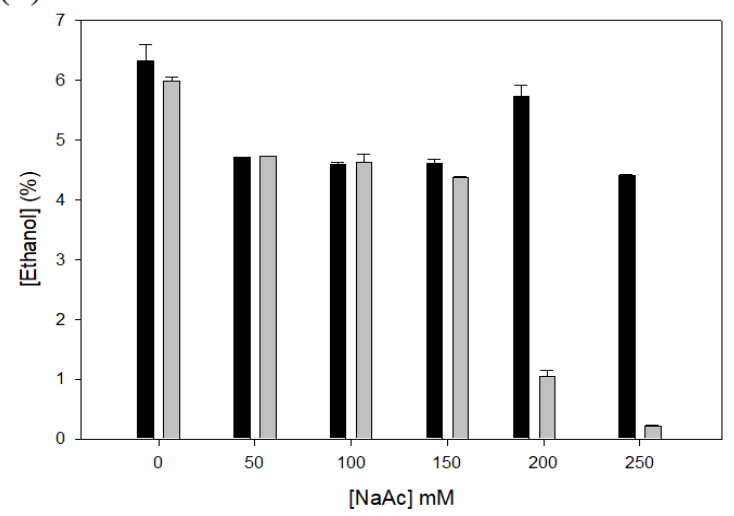

Fig. 4. The effect of the increasing NaAc level $(0-250 \mathrm{mM})$ on ethanol production and glucose consumption in $100 \mathrm{~g} / \mathrm{l}$ glucose with no control $\mathrm{pH}$ at $24 \mathrm{~h}$ fermentation time. A, B: Glucose and ethanol concentrations, respectively. $\square$ : AcR/2-12; $\square$ ATCC 31823.

TABLE I: FERMENTATION RESUltS FOR Z. MobiLIS MutANT ACR/2-12 AND WILD-TYPE ZM481 AT DifFERENT NAAC CONCENTRATIONS WITH No CONTROL $\mathrm{PH}$ (24 H INCUBATION TIME)

\begin{tabular}{|c|c|c|c|c|c|c|c|c|}
\hline \multirow[t]{2}{*}{ Strain } & \multicolumn{4}{|c|}{ Fermentation conditions } & \multicolumn{4}{|c|}{ Performance results } \\
\hline & $\begin{array}{c}\text { [NaAc] } \\
\mathrm{mM}\end{array}$ & Temp $\left({ }^{\circ} \mathrm{C}\right)$ & Final $\mathrm{pH}$ & $\begin{array}{c}\text { Ethanol } \\
\text { Production } \\
(\%)\end{array}$ & $\begin{array}{l}\text { Ethanol process } \\
\text { yield }^{\mathrm{a}}(\%) \mathrm{w} / \mathrm{w}\end{array}$ & $\begin{array}{c}\text { Glucose in } \\
\text { the flask } \\
(\%)\end{array}$ & $\begin{array}{c}\text { Glucose } \\
\text { consumed }^{\mathrm{b}}(\%) \\
\text { w/w }\end{array}$ & $\begin{array}{c}\text { O.D } \\
600 \mathrm{~nm}\end{array}$ \\
\hline \multirow{6}{*}{$\mathrm{AcR} / 2-12$} & 0 & 30 & 4.6 & 6,32 & 63,8 & 0,10 & 99 & 5,6489 \\
\hline & 50 & 30 & 5.4 & 4,7 & 47,3 & 0,06 & 99 & 3,3684 \\
\hline & 100 & 30 & 5.6 & 4,6 & 46,5 & 0,10 & 99 & 2,7112 \\
\hline & 150 & 30 & 5.6 & 4,6 & 46,3 & 0,06 & 99 & 2,4583 \\
\hline & 195 & 30 & 5.6 & 5,7 & 58,2 & 0,22 & 98 & 2,1784 \\
\hline & 250 & 30 & 5.8 & 4,4 & 44 & 0,10 & 99 & 1,9917 \\
\hline \multirow{6}{*}{ ZM 481} & 0 & 30 & 4.5 & 5.9 & 64.7 & 0,89 & 91.12 & 3,5983 \\
\hline & 50 & 30 & 5.3 & 4.7 & 47.5 & 0,10 & 99 & 2,3500 \\
\hline & 100 & 30 & 5.5 & 4.6 & 46.5 & 0,10 & 99 & 1,9517 \\
\hline & 150 & 30 & 5.6 & 4.4 & 45.9 & 0,42 & 95.8 & 1,7850 \\
\hline & 195 & 30 & 5.6 & 1.05 & 43.2 & 7,57 & 24.3 & 0,5005 \\
\hline & 250 & 30 & 5.7 & 0.22 & 6.14 & 6,42 & 35.8 & 0,1258 \\
\hline
\end{tabular}

${ }^{\text {a }}$ Ethanol produced divided by glucose consumed

${ }^{\mathrm{b}}$ Glucose consumed divided by initial glucose present 
The summary about fermentation process on $100 \mathrm{~g} / \mathrm{l}$ glucose containing the increasing $\mathrm{NaAc}$ level at 24 hours by Z. mobilis mutant AcR/2-12 and the wild-type ZM481 are shown in Table I. The highest ethanol yield was obtained by AcR/2-12 in the absence of NaAc, because there was no inhibitor compound in the fermentation medium. Differently, the growth of ZM481 was significantly inhibited in the presence of $195 \mathrm{mM}$ and only $2.2 \mathrm{~g} / \mathrm{l}$ ethanol was produced, while AcR/2-12 was able obtained $57 \mathrm{~g} / \mathrm{l}$ of ethanol with the ethanol yield (Yp/s) of $58.8 \mathrm{~g} / \mathrm{g}$ within $24 \mathrm{~h}$ fermentation time. During fermentation, the $\mathrm{pH}$ will be shifted to lower $\mathrm{pH}$ due to the releasing $\mathrm{CO}_{2}$ as a side product of ethanol fermentation. More interestingly, in the presence of $195 \mathrm{mM} \mathrm{NaAc}, Z$. mobilis mutant AcR/2-12 produced ethanol as high as in the absence of NaAc.

The effect of $\mathrm{NaAc}$ also affected ethanol production and glucose consumption (Fig. 6). The increasing NaAc level reduced ethanol production and inhibited the glucose consumption. As showed in Fig. 5, the cell concentration decreased as NaAc increased, and $100 \mathrm{mM}(8.2 \mathrm{~g} / \mathrm{l}) \mathrm{NaAc}$ was the limited concentration which might allow these two strains to survive and produce ethanol efficiently. Meanwhile, above that concentration $(100 \mathrm{mM})$ the inhibition of $\mathrm{NaAc}$ was increased, thus it was difficult for AcR/2-12 and ZM481 to adapt in high concentration of $\mathrm{NaAc}$.

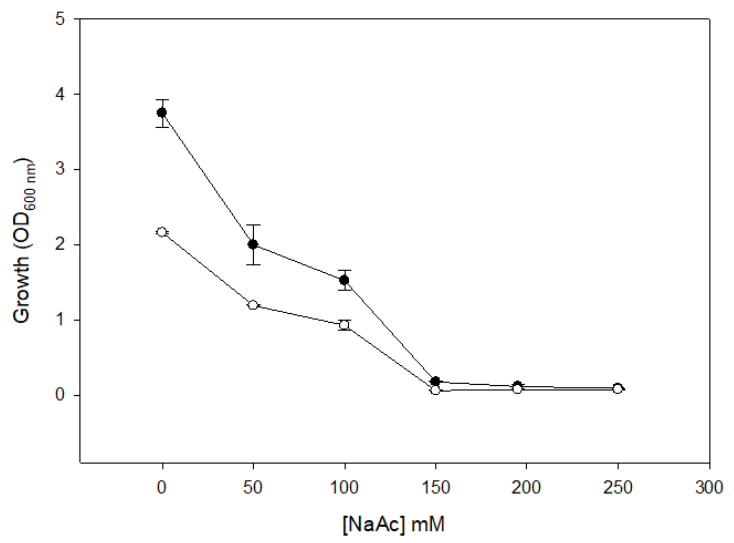

Fig. 5. The effect of the increasing NaAc level $(0-250 \mathrm{mM})$ on Z. mobilis growth in $100 \mathrm{~g} / \mathrm{l}$ glucose ( $\mathrm{pH} 5$ and $24 \mathrm{~h}$ fermentation time). $\bullet$ : AcR/2-12 (Growth); $\bigcirc:$ ZM481 (Growth).

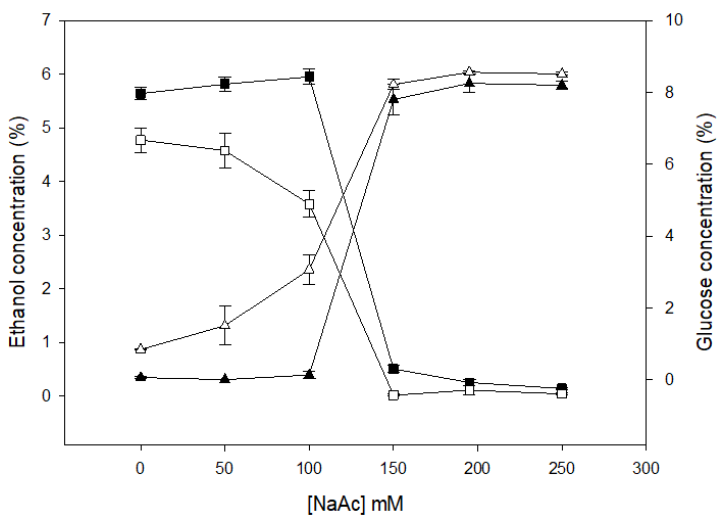

Fig. 6. The effect of the increasing NaAc level $(0-250 \mathrm{mM})$ on ethanol production and glucose consumption in $100 \mathrm{~g} / \mathrm{l}$ glucose ( $\mathrm{pH} 5$ and $24 \mathrm{~h}$ fermentation time). $\boldsymbol{\Delta}:$ AcR/2-12 (Glucose) ; $\triangle:$ ZM481 (Glucose) ; AcR/2-12 (Ethanol ); $\square:$ ZM481 (Ethanol).

Generally, the increasing NaAc level in fermentation medium reduced ethanol production and inhibited glucose consumption. However, the effect of the increasing NaAc level was different at $\mathrm{pH} 5$ and with no control $\mathrm{pH}$. At $\mathrm{pH} 5$, the inhibition level of sodium acetate was higher than with no control pH. Here, AcR/2-12 and ZM481 were inhibited by similar concentration of $\mathrm{NaAc}$, above $100 \mathrm{mM} \mathrm{NaAc}$. Whereas, above $\mathrm{pH} 5$ (with no control $\mathrm{pH}$ ), AcR/2-12 and ZM481 showed tolerance ability differently. AcR/2-12 was able to tolerate up to $250 \mathrm{mM} \mathrm{NaAc}$, while ZM481 was inhibited significantly at $195 \mathrm{mM} \mathrm{NaAc}$.

\section{The Effect of $195 \mathrm{mM} \mathrm{NaAc}$ on the Growth and Ethanol Production at $\mathrm{pH} 5$}

According to previous results, $195 \mathrm{mM} \mathrm{NaAc}$ exhibited the strongest inhibition for ZM 481 but not to AcR/2-12 with no control $\mathrm{pH}$. In the presence of $\mathrm{NaAc}$ at $\mathrm{pH} 5$, the AcR/2-12 produced higher concentration of ethanol after the glucose was completely utilized in $126 \mathrm{~h}$ with an ethanol yield of 0,62 g/g (Fig. 7).
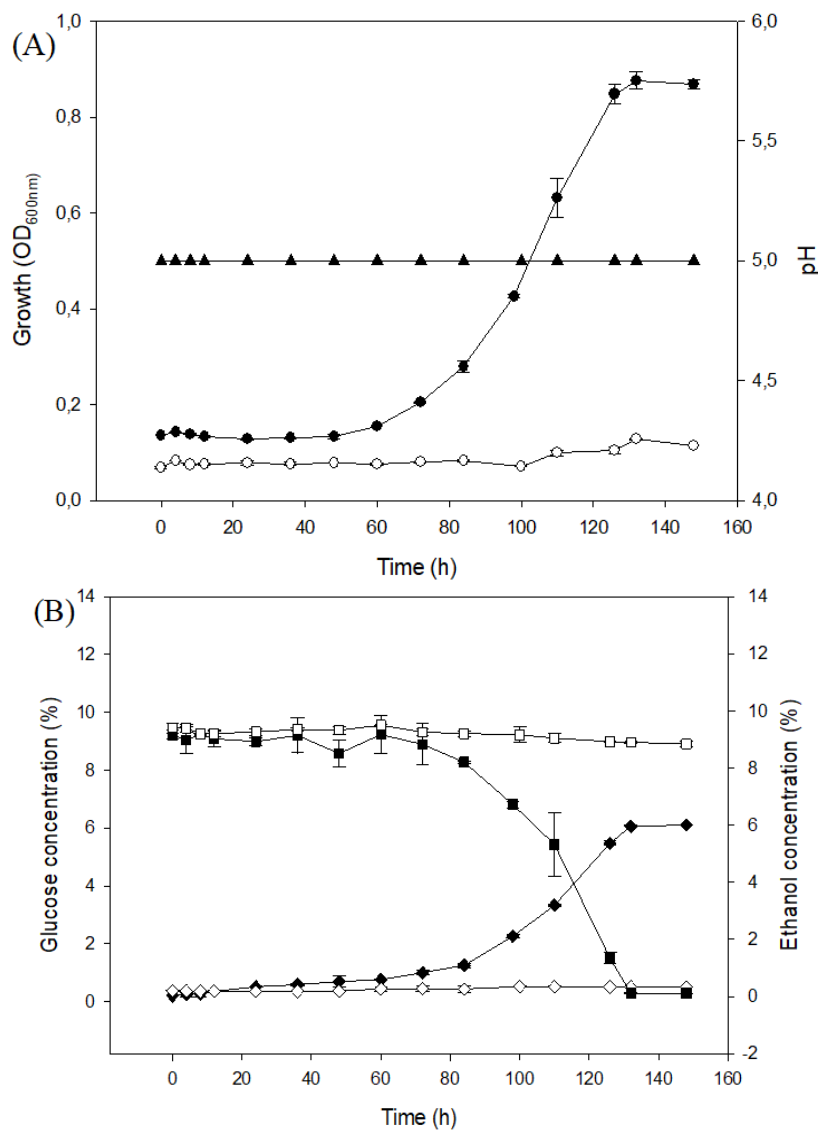

Fig. 7. (A) The growth and $\mathrm{pH}$ (B) Ethanol and glucose concentration from fermentation of Z. mobilis mutant AcR/2-12 and wild-type ZM481 in $100 \mathrm{~g} / \mathrm{l}$ glucose containing $195 \mathrm{mM}$ or $12 \mathrm{~g} / \mathrm{l} \mathrm{NaAc}$ at $\mathrm{pH} 5$ and $30^{\circ} \mathrm{C}$. $\bullet$ : AcR/2-12 (Growth) ; O : ZM481 (Growth); $\boldsymbol{\Lambda}:$ AcR/2-12 and ZM481 (pH) ; AcR/2-12 (Glucose ) ; $\square:$ ZM481 (Glucose) ; : AcR/2-12 (Ethanol) ; $\diamond:$ ZM481 (Ethanol).

In the wild-type ZM481, there were neither growth nor ethanol were observed in this condition. ZM AcR/2-12 took longer a log phase and reached stationary phase was about 132 or $148 \mathrm{~h}$ in the presence of $195 \mathrm{mM} \mathrm{NaAc}$. The possible reason for this condition was at $\mathrm{pH} 5$ the concentration of un-dissociated (HAc) form increases and penetrates easier into the cell membrane led to increase acidification of cell membrane. Wang also mentioned in his study, that concentrations of acetic acid greater than $10 \mathrm{~g} / \mathrm{l}$ were tolerated if the $\mathrm{pH}$ was above 5.0. At $\mathrm{pH} 6.0$, the specific growth rate with $12 \mathrm{~g} / \mathrm{l}$ acetic acid was quite similar to that in 
the absence of acetic acid, although the growth yield was decreased by about 40 . In another study also mentioned that if the concentration of acetic acid was too low, the effect of $\mathrm{pH}$ on the growth inhibition would be small, but if the concentration was too high, the effect would be too severe for cells to overcome [7], [20], [21].

\section{CONCLUSION}

This study reported that the effect of sodium acetate was related with $\mathrm{pH}$. The growth of AcR/2-12 and ZM481 at $\mathrm{pH} 5$ was inhibited by NaAc concentration above $100 \mathrm{mM}$. Whereas, with no control $\mathrm{pH}, \mathrm{AcR} / 2-12$ was able to tolerate sodium acetate up to $250 \mathrm{mM}$, while wild-type was significantly inhibited. The mutant strain 2-12 in fermentation medium contained $10 \%$ glucose and supplemented with $195 \mathrm{mM} \mathrm{NaAc}$ at $\mathrm{pH} 5$ was able to grow well and ethanol concentration reached $60 \mathrm{~g} / \mathrm{l}$ with the ethanol yield approached $0.62 \mathrm{~g} / \mathrm{g}(\mathrm{Yp} / \mathrm{s})$ in $148 \mathrm{~h}$, whereas ZM481 was unable to grow. Concurrently, with no control $\mathrm{pH}$, the glucose was completely consumed in $24 \mathrm{~h}$ by AcR/2-12 and ethanol concentration reached $57 \mathrm{~g} / \mathrm{l}$ ethanol with the ethanol yield of $0.58 \mathrm{~g} / \mathrm{g}$ in the presence of $195 \mathrm{mM}$ NaAc.

\section{ACKNOWLEDGMENT}

The authors wish to thank to my advisors, Assistant Professor Dr. Chia-Wen Hsieh, and Associate Professor Dr. Yi-Ling Yang. This work was supported by the grant (NSC96-2313-B-415-011-MYS) from National Science Council, Taiwan, Republic of China.

\section{REFERENCES}

[1] F. M. Gírio et al., "Hemicelluloses for fuel ethanol: A review," Bioresource Technology, vol. 101, no. 13, pp. 4775-4800, 2010.

[2] D. Saigal, "Yeast strain development for ethanol production," Indian J Microbiol, vol. 33, pp. 159-168, 1993.

[3] K. J. Lee et al., "High productivity ethanol fermentations with Zymomonas mobilis using continuous cell recycle," Biotechnology Letters, vol. 2, no. 11, pp. 487-492, 1980.

[4] G. A. Sprenger, "Carbohydrate metabolism in Zymomonas mobilis: A catabolic highway with some scenic routes," FEMS Microbiology Letters, vol. 145, no. 3, pp. 301-307, 1996.

[5] M. A. Franden, P. T. Pienkos, and M. Zhang, "Development of a high-throughput method to evaluate the impact of inhibitory compounds from lignocellulosic hydrolysates on the growth of Zymomonas mobilis," Journal of Biotechnology, vol. 144, no. 4, pp. 259-267, 2009.

[6] A. Aden and T. Foust, "Technoeconomic analysis of the dilute sulfuric acid and enzymatic hydrolysis process for the conversion of corn stover to ethanol," Cellulose, vol. 16, no. 4, pp. 535-545, 2009.

[7] H. G. Lawford and J. D. Rousseau, "Effects of pH and acetic acid on glucose and xylose metabolism by a genetically engineered ethanologenicEscherichia coli," Applied Biochemistry and Biotechnology, vol. 39, no. 1, pp. 301-322, 1993.

[8] P. T. Pienkos and M. Zhang, "Role of pretreatment and conditioning processes on toxicity of lignocellulosic biomass hydrolysates," Cellulose, vol. 16, no. 4, pp. 743-762, 2009.

[9] H. B. Klinke, A. B. Thomsen, and B. K. Ahring, "Inhibition of ethanol-producing yeast and bacteria by degradation products produced during pre-treatment of biomass," Applied Microbiology and Biotechnology, vol. 66, no. 1, pp. 10-26, 2004.

[10] E. Palmqvist and B. Hahn-Hägerdal, "Fermentation of lignocellulosic hydrolysates. I: inhibition and detoxification," Bioresource Technology, vol. 74, no. 1, pp. 17-24, 2000.

[11] E. Palmqvist and B. Hahn-Hägerdal, "Fermentation of lignocellulosic hydrolysates. II: inhibitors and mechanisms of inhibition," Bioresource Technology, vol. 74, no. 1, pp. 25-33, 2000.
[12] M. T. A. JRM, A. Petersson, B. Hähn-Hägerdal, G. Lidén, M. F. Gorwa-Grauslund, "Increased tolerance and conversion of inhibitors in lignocellulosic hydrolysates by Saccharomyces cerevisiae," J. Chem Technol Biotechnol, vol. 82, no. 4, pp. 340-349, 2007.

[13] E. L. Joachimsthal and P. L. Rogers, "Characterization of a high-productivity recombinanst strain of zymomonas mobilis for ethanol production from glucose/xylose mixtures, in twenty-first symposium on biotechnology for fuels and chemicals," in Proc. the Twenty-First Symposium on Biotechnology for Fuels and Chemicals, May 2-6, 1999, in Fort Collins, Colorado, M. Finkelstein and B. H. Davison, Eds., Humana Press: Totowa, NJ, pp. 343-356, 2000.

[14] L. J. Turton, D. B. Drucker, and L. A. Ganguli, "Effect of glucose concentration in the growth medium upon neutral and acidic fermentation end-products of Clostridium bifermentans, Clostridium sporogenes and Peptostreptococcus anaerobius," Journal of Medical Microbiology, vol. 16, pp. 61-67, 1983.

[15] J. C. Baratti and J. D. Bu'lock, "Zymomonas mobilis: A bacterium for ethanol production," Biotechnology Advances, vol. 4, no. 1, pp. 95-115, 1986.

[16] J. J. Allias, E. F. Torres, and J. Baratti, "Continuous production of ethanol with Zymomonas mobilis growing on Jerusalem artichoke juice," Biotechnol Bioeng, vol. 29, no. 6, pp. 778-782, 1987.

[17] S. S. Kesava, S. K. Rakshit, and T. Panda, "Production of ethanol by Zymomonas mobilis: The effect of batch step-feeding of glucose and relevant growth factors," Process Biochemistry, vol. 30, no. 1, pp. 41-47, 1995.

[18] S. Cromie and H. W. Doelle, "Relationship between maintenance energy requirement, mineral salts and efficiency of glucose to ethanol conversion by Zymomonas mobilis," Biotechnology Letters, vol. 2, no. 8, pp. 357-362, 1980.

[19] P. S. Panesar, S. S. Marwaha, and J. F. Kennedy, "Zymomonas mobilis: An alternative ethanol producer," Journal of Chemical Technology \& Biotechnology, vol. 81, no. 4, pp. 623-635, 2006.

[20] H. G. Lawford and J. D. Rousseau, "The pH-dependent energetic uncoupling ofZymomonas by acetic acid," Applied Biochemistry and Biotechnology, vol. 45, no. 1, pp. 437-448, 1994.

[21] Y. Wang, "Development of acetic-acid tolerant Zymomonas mobilis strains through adaptation," 2008.

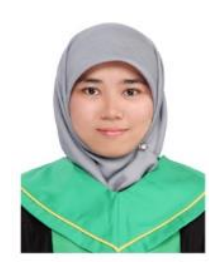

Puspa Puspita was born in Curup on $17^{\text {th }}$ July, 1987 She got her bachelor degree from Department of Department of Biochemistry, Faculty of Mathematics and Natural Sciences, Bogor Agricultural University in 2010, then in 2012 she got her master degree from Department of Biochemical Science and Technology, at National Chiayi University (NCYU), Chiayi, Taiwan.

She has been working as a junior lecture of Department of Biochemistry, Faculty of Mathematic and Life Sciences at Bogor Agricultural University. She has many experiences during work as a staf of Department of Biochemistry. She often attends conference, workshop, and seminars in her university or in another university in indonesia. She has been doing with others colleague to do some expriments with others colleague in Biochemistry of Department in Bioenergy field, Enzymology and Molecular Biology. She has experience also as a committee of Summer course program at Department of Biochemistry in 2017. Her researchs are published ini in journal and proceeding in national and international.

Mrs. Puspa has been a member in professional societies like the IUBMB Indonesia branch.

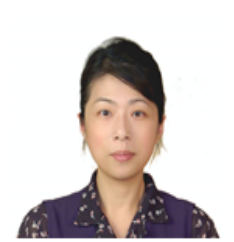

Hsieh Chia-Wen was born in Taipei on $23^{\text {rd }}$ July, 1969. She got her bachelor degree from National Taiwan University in agriculture chemistry, Taipei, Taiwan in 1992, then in 1994 she got her master degree in agriculture chemistry at National Taiwan University, Taipei, Taiwan. She got her Ph.D degree from Tokyo University, Japan in agriculture in 1998.

She has been a lecture and an assistance professor of Department of Microbiology, Immunology and Biopharmaceuticals at National Chiayi University, Chiayi, Taiwan. In 2006, she established the Lab of Applied Microbiology (LAM) which exclusively focuses on improving scientific understanding of the biology of Industrial Bacteria, such as Zymomonas, Clostridium, Bacillus, Streptomyces and Lactic Acid Bacteria. She and her team also apply the genetic engineering and response surface methodology approaches to maximise the production of the biobutanol andbioethanol production from Clostridial and Zymomonas, respectively. She often attends conference, workshop, and seminars in France, Switzerland, Canada and other countries in the world to support her expertise. Her researchs are 
published in journal and proceeding national and international journals and conferences.

Dr. Hsieh also has some patents from her research in 2009, 2010, 2011, and 2012.

Chang Yao-Sheng was born in Kaohsiong on 28th January, 1990. He got his bachelor degree from National Chiayi University in Department of Microbiology, Immunology and Biopharmaceuticals, Chiayi, Taiwan in 2012, then in 2014 he got his master degree in the same Department and University.
During his study, Mr. Chang often attends seminars, conferences in another university in Taiwan to encourage his study.

Mr. Chang has been working as $\mathrm{R}$ and $\mathrm{D}$ engineer in one of private company in Taiwan. 